\title{
PERCEPTION AND READINESS TOWARDS INTEGRATION OF LEARNING MANAGEMENT SYSTEM (LMS) INTO OPEN AND DISTANCE EDUCATION
}

\author{
Tolulope Fashina ${ }^{1} \&$ Oluwajoba Ibrahim Adisa ${ }^{2}$ \\ ${ }^{1}$ Department of Optamology, Emory University \\ ${ }^{2}$ Department of Learning Sciences, Clemson University \\ Author email: iadisa@g.clemson.edu
}

\begin{abstract}
The rapid development of information and communication technologies has led to the use of new and digital technologies in education which involves combinations of text, graphics, audio, video, animations and other eLearning resources such as authoring tools, Learning Management System (LMS), Mobile learning and others. Arguably, using LMS leaves much to be desired. The inherent problem here is that the future of extensive adoption of ICT via LMS to enhance and promote classroom interaction in Open and Distance Learning (ODL) is bleak. This is worrisome given that the country is lagging far behind in the innovative use of this web 2.0 technology to impart knowledge. Further, the low-level application of LMS in instruction connotes the loss of inherent advantages in its adoption. Also, the online setting which makes students less nervous and interactive, sharing of ideas and viewpoints; and a host of other benefit will be lost. While evidence has shown that LMS is not a new phenomenon, the use of LMS in ODL is still at its infancy, particularly in Nigeria. Research in this area is rare. A quick search on prominent research databases could testify that. It is on this thrust that this study investigates University of Ibadan undergraduate students' perceived roles and readiness towards integration of learning management system into teaching and learning.
\end{abstract}

Keywords: Learning Management System (LMS), perceived role, readiness, integration

\section{Introduction}

Technology has inevitably become the most powerful tool in almost every aspect of human's daily life. It is regarded as a major revolution and this has a significant impact on education. The use of information and communication technology (ICT) and the Internet are the new paradigm shift in learning in the $21^{\text {st }}$ century. These technological advancements allow people to easily access, gather, analyze, and transfer data and knowledge. According to Horton (2003), trends in technology influence education and knowledge management. Both in Nigeria and other African countries, the number of students joining undergraduate level courses has been on a sharp rise for the past decades. Lectures are being held in larger lecture theatres as lecturing space is becoming less available and student-teacher interaction is next to none. Improving the current scenario is hindered by shrinking funds and resources in relation to the ever increasing student intakes. 
In Nigeria, very few of our conventional universities are now carrying out their ODL activities through one form of ICT or the other. While the urge to embark on online instruction is still a dream to some because their infrastructure for ICT is very weak, the rapid expansion of ICTs and Internet Technologies in Nigeria offer an opportunity for some institutions to embark on the use of learning management system (LMS). Learning Management system provides unprecedented ways for education delivery (Garrison, 2009). LMS system allows students to download and upload files, participate in chat and discussion boards, as well as take assessments. Students are also able to view grades as well as contact the teacher and classmates. An LMS is a step above a classroom website which is a more static approach to giving classroom information (Waters, 2007).

As described in (Ellis, 2009) a robust LMS should be able to do the following:

- Centralize and automate administration

- Use self-service and self-guided services

- $\quad$ Assemble and deliver learning content rapidly

- $\quad$ Consolidate training initiatives on a scalable web-based platform

- $\quad$ Support portability and standards and

- $\quad$ Personalize content and enable knowledge reuse

Furthermore, as outlined by Mullinix and McCury (2003), the potential uses of an LMS to improve the teaching and learning process include increased access to course content and improved communication among academic staff and students. As noted by O'Quinn and Corry (2002) who support Mullinix and McCurry's findings, a web-based course expands the learning time because content is readily accessible. Another significant benefit of LMS is assessment and evaluation (Smith, 2006). Online assessments incorporate a variety of metacognitive strategies including selfmonitoring, personal management, focus, and planning objectives. Smith notes that LMS resources permit tutorials, simulated and real world models, problem solving and role-playing activities. The social and affective strategies incorporated through an LMS are the collaboration and cooperation that occurs in discussion boards, group pages, and chat sessions.

Wang (2007) adds that the electronic tools that are available in an LMS provide academic staff with a comprehensive approach to organizing course content and completing administrative procedures. Distribution of reading materials and handouts are completed through electronic, documents and files, thereby eliminating additional clerical tasks (Pittinsky, 2004). Students need to take an active approach to learning if they are to be successful LMS learners (Pallof and Praftt, 2008) Consequently students need to be involved in discussions, be prepared to speak out, develop solutions, and work within minimal guidelines. Further, generating deeper level of understanding requires students to work collaboratively (Chang and Fisher, 2003). Zariski and Styles (2000) suggest that students need to become self-directed learners, which require them to be highly selfregulated, be responsible for organizing their learning, and be reflective. Students who are selfdirected learners will understand content plus have a positive attitude towards themselves as 
learners. This will enable them to reflect on their learning and will provide the motivation to continue learning throughout life (Clayton, 2003). Armarego \& Roy (2000) argue that by having students complete reflective journals, or some other measure of self-assessment, they have opportunities for reflection and introspection so that they can make sense of the experiences they have gained. A "LMS learner must be able to identify and prioritize his or her personal skill gaps" and "manage the learning experiences, including setting clear goals, establishing specific plans, and securing needed resources" (Birch, 2002). Quek and Wong (2003, p. 289) warn that being successful in the LMS environment requires that students understand the purpose and function of learning management system (LMS). It is in this light that this study investigates University of Ibadan undergraduate students' perceived roles and readiness towards integration of learning management system into teaching and learning.

\subsection{Research Questions}

This study aims at answering the following research questions:

1. Is there any significant difference in the level of readiness toward learning management system between male and female undergraduate student?

2. Is there any significant difference in the perceived role towards learning management system between male and female undergraduate students?

3. Is there any significant difference in the level of readiness and perceived role towards learning management system between 200 and 300 academic level students?

4. Does subject combination have any significant difference on their readiness and perceived role towards learning management system?

\section{Research Design}

This study adopted descriptive research design. Simple survey method is used to carry out the study. This is because the study aimed at capturing perceived roles and readiness towards integration of learning management system into teaching and learning among the target population.

\section{Population of the Study}

The population for this study is undergraduate students of the faculty of education, university of Ibadan, Ibadan. The faculty of education consists of nine department namely, teacher education, guidance and counseling, adult education, special education, human kinetic and health education, educational management, social work, library, archival and information studies.

\section{Sample and Sampling Technique}

A total of three hundred and sixty students drawn from the target population participated in the study. The purposive sampling technique was used to carry out the study. The reason for this was that integration of learning management system into teaching and learning in the University of 
Ibadan is gradually taking root in the faculty of education but not in all the department. Thirty students each in 200 and 300 levels from the following department were selected to form the sample.

\section{Research Instrument}

The instrument was a self-prepared questionnaire known as undergraduate student's perceived poles and readiness towards integration of learning management system into teaching and learning. The first section of the questionnaire is on personal data of the responsible. It has five items, department, sex, age, level, and teaching subject. Section B is on computer and internet usage with six questions while section $\mathrm{C}$ bordered on computer knowledge and skills eleven questions. Section D centered on "students level of readiness towards learning management system" with seventeen questions while section E based on "students perceived role towards learning management system" with fourteen questions. The respondents are to indicate their answer on a four points linker scale of strongly disagree, disagree, strongly agree, and agree. This procedure sought to ensure the appropriateness of the asked questions and eliminate any ambiguity. A copy of the questionnaire was submitted to the project supervisor for assessment so as to establish face validity. The reliability of the instrument was established through a pilot study on forty students among the target population. Cronbach Alpha coefficient was calculated by using SPSS to estimate the reliability of the instrument. A reliability level of 0.8 was obtained and this showed that the instrument was a reliable one.

\section{Procedure for data collection}

The researcher visited some department in the faculty of education and administered the questionnaire. The questionnaire was administered to the students by the researcher, and was immediately collected in order to ensure that the entire instrument was retrieved.

\section{Method of Data Analysis}

SPSS (Statistical Package for Social Scientist) was employed to analyze the data. t-test and ANOVA were used to find the difference between two groups and among groups respectively.

\section{Results of the Findings and Discussion}

Research question 1: Is there any significant difference in the level of readiness toward learning management system between male and female undergraduate student?

Table $1 \mathrm{t}$ - test of level of readiness toward learning management system by gender 


\begin{tabular}{|l|l|l|l|l|l|l|l|}
\hline Gender & $\mathrm{N}$ & Mean & Std Dev'n & Std error & $\mathrm{T}$ & $\mathrm{df}$ & $\mathrm{P}$ \\
\hline Male & 154 & 47.05 & 8.041 & .648 & & & \\
\cline { 1 - 4 } Female & 206 & 45.02 & 7.334 & .511 & 2.490 & 358 & $.013^{*}$ \\
\hline
\end{tabular}

Ns $=$ Not significant at $\mathrm{p}<0.05$

Table1 reveals that the mean readiness towards management system of male undergraduate students was 47.05 while that of their female counterparts was 45.02. Male students had greater readiness for management students than the female students. It could also be deduced from the table that there exists a significant difference $(t=258=2.490, \mathrm{p}<0.75)$ between male and female undergraduate students towards learning management system.

Research question 2: Is there any significant difference in the perceived role towards learning management system between male and female undergraduate students?

\begin{tabular}{|l|l|l|l|l|l|l|l|}
\hline Gender & $\mathrm{N}$ & Mean & Std dev'n & Std error & $\mathrm{t}$ & $\mathrm{df}$ & $\mathrm{P}$ \\
\hline Male & 154 & 43.14 & 7.232 & .583 & & & \\
\hline Female & 206 & 42.97 & 7.709 & .537 & .207 & 358 & $.836 \mathrm{~ns}$ \\
\hline
\end{tabular}

Ns $=$ Not significant at $\mathrm{p}<0.05$

Table: t-test of undergraduate students perceived role by gender

From table 2, the male students slightly had a higher perception of their roles towards learning management system $(x=43.14)$ than female students with mean score of 42.97. the $t$ - value of 0.207 at 358 degree of freedom indicates that there is no significant difference in the perceived role between male and female students towards learning of management system $p=.836$ which is greater than 0.05 . It implies that student's perceptions of their roles towards learning of management system are the same for both male and female students.

Research Question 3: Is there any significant difference in the level of readiness and perceived role towards learning management system between 200 and 300 academic level students?

Table 3: t-test of level of readiness towards management system by academic level

\begin{tabular}{|l|l|l|l|l|l|l|l|}
\hline $\begin{array}{l}\text { Academic } \\
\text { level }\end{array}$ & $\mathrm{N}$ & Mean & Std devn & Std error & $\mathrm{t}$ & $\mathrm{df}$ & $\mathrm{P}$ \\
\hline 200 level & 180 & 45.40 & 7.421 & .593 & -1.212 & 358 & $.226 \mathrm{~ns}$ \\
\hline
\end{tabular}




\begin{tabular}{|l|l|l|l|l|l|}
\hline 300 level & 180 & 46.38 & 7.958 & .593 & \\
\hline
\end{tabular}

$\mathrm{ns}=$ Not significant at $\mathrm{p}<0.05$

Table 3 indicates that the mean readiness score of 200 level students was 45.40 and that of 300 level students was 46.38, 300 level students had greater level of readiness towards learning management system. Table 3 also reveal that there is no significant difference in level of readiness towards management system between 200 and 300 levels student $(\mathrm{t}(358)=-1.212, \mathrm{p}>0.05)$.

Table 4: t-test of Perceived role toward management system learning by Academic levels.

\begin{tabular}{|l|l|l|l|l|l|l|l|}
\hline $\begin{array}{l}\text { Academic } \\
\text { level }\end{array}$ & $\mathrm{N}$ & Mean & Std dev'n & Std error & $\mathrm{t}$ & $\mathrm{df}$ & $\mathrm{P}$ \\
\hline 200 level & 180 & 43.25 & 6.384 & .513 & .527 & 258 & $.599 \mathrm{~ns}$ \\
\cline { 1 - 5 } 300 level & 180 & 42.83 & 6.081 & .602 & & & \\
\hline
\end{tabular}

ns $=$ Not significant at $\mathrm{p}<0.05$

Table 4 reveals that the mean perceived role score of 200 level students was 43.25 while that of 300 level students was 42.83 . The t-value of .527 at 358 degree of freedom indicates that there is no significant difference in perceived roles between 200 and 300 level student's towards learning management system for $\mathrm{p}=.599$ is greater than 0.05 . Therefore, academic levels of undergraduate students had no significant influence on student's perceived role towards learning management system.

Research question 4: Does subject combination have any significant difference on their readiness and perceived role towards learning management system?

Table 5: Descriptive of student's readiness towards management system by subject combination.

\begin{tabular}{|l|l|l|l|l|}
\hline Subject combination & N & Mean & Std deviation & Std error \\
\hline Sciences & 95 & 46.48 & 8.474 & .869 \\
\hline Social sciences & 222 & 45.86 & 7.345 & .493 \\
\hline Arts \& Languages & 43 & 44.74 & 7.743 & 1.181 \\
\hline Total & 360 & 45.59 & 7.699 & .406 \\
\hline
\end{tabular}


Table 6 ANOVA of students' readiness for learning management system by subject combination

\begin{tabular}{|l|l|l|l|l|l|}
\hline & Sum of squares & Df & Mean square & F & P \\
\hline Between groups & 90.191 & 2 & 45.096 & & \\
\cline { 1 - 4 } Within groups & 21190.584 & 357 & 59.357 & $.760 \quad .496 \mathrm{~ns}$ \\
\cline { 1 - 4 } Total & 21280.775 & 359 & & & \\
\hline
\end{tabular}

Ns = not significant at pc 0.05

Descriptive result on table 6 reveals that undergraduate students with science based teaching subjects had readiness mean score of 46.48, those that are with social science teaching subject had 45.86 and the rest who are Arts and Language based had 44.74 mean score of their readiness for leaving management system. Science- based students had the highest readiness, followed by Social Science students while Arts and Language students had the least readiness for learning management information system. Table 6 shows that the difference in these mean scores was not significant $(\mathrm{f}(2,257)=.760, \mathrm{P}>0,05)$ on students readiness for learning management system. It is therefore inferred that subject combination of students does not have any significant influence on their readiness for learning management system.

Table 7: Descriptive of students perceived roles towards learning management system

\begin{tabular}{|l|l|l|l|l|}
\hline Subject combination & $\mathrm{N}$ & Mean & Std deviation & Std error \\
\hline Sciences & 95 & 43.51 & 7.692 & .789 \\
\hline Social sciences & 222 & 42.73 & 7.463 & .501 \\
\hline Arts \& Languages & 43 & 43.65 & 7.332 & 1.118 \\
\hline Total & 360 & 43.04 & 7.499 & .395 \\
\hline
\end{tabular}

Table 8 ANOVA of students perceived roles towards learning management system by subject combination

\begin{tabular}{|l|l|l|l|l|l|}
\hline & Sum of squares & Df & Mean square & F & P \\
\hline Between groups & 56.621 & 2 & 29.311 & & \\
\cline { 1 - 3 } Within groups & 20120.754 & 357 & 56.386 & .530 & $.595 \mathrm{~ns}$ \\
\hline
\end{tabular}




\begin{tabular}{|l|l|l|l|l|}
\hline Total & 20188.375 & 359 & & \\
\hline
\end{tabular}

$\mathrm{ns}=$ not significant at $\mathrm{P}>0,05$

The perceived roles mean score for students with Science based teaching subject was 43.51, those of Social Science based was 42.73 and the Arts and Languages based students had 43.65 students who are of Arts \& Languages slightly had higher perception of their roles in learning management system followed by Science students while Social Science students had the least (table 4.17). Table 8 reveals that there is no significant difference in students' perceived roles towards learning management system. Consequently, subject combination of students did not have any significant influence on their perceived roles towards learning management system.

The study revealed that there was a significant difference in computer knowledge and skill experience of the respondents towards integration of LMS into teaching and learning. This means that students who were computer literate were more prepared to engage in LMS than those who were computer phobia. This study agreed with Ben (2007) who found that computer knowledge and skill were essential ingredients for a successful implementation of LMS in Iowa State University. The data showed that there was no correlation between age and perceived role and readiness towards integration of LMS into teaching and learning. Learners of different age had the same perception of their roles, and equally ready to use LMS. This result agreed with Atienzavenal (2009) study which investigated the readiness of computer engineering students of TIPQC to online learning. In fact some of the items used to measure perceived readiness in this study were adopted from Atienza-venal (2009).

There was no significant difference between male and female students' perceived role towards LMS integration into teaching and learning; whereas there was a significant difference in the perceived readiness towards LMS. This might be due to the fact male students were always eager to engage in practical work than their female counterpart. There was no significant difference in the level of study of respondents, and subject combination of students towards integration of LMS into teaching and learning. This means that the performance of learners LMS has nothing to do with number of years they have studied in the university, and the subjects they are studying.

\section{Conclusion}

LMS area powerful technology that have yet to reach their full potential and are very important for the Information Age paradigm of education. Because of their importance, greater care and understanding needs to be used when applying the term in research literature. By coming to understand of what LMS are and how complementary technologies can be integrated with an LMS, researcher and practitioners will better be able to communicate regarding the state and future of computers in education. Studies about the implementation and effectiveness are needed. These studies should examine more closely what features these products offer as well as identify what additional features are needed. Teacher and other stakeholder perceived role and readiness of LMS 
should be described. Furthermore, more research is needed in the area of learning object authoring and adherence to standards. It is important for institutions management to keep an eye on the needs of today's learners, how technology can be maximized to best meet those needs, and to conduct research to help guide decisions and future application of technology.

\section{Recommendation}

Based on the finding of the study, the following recommendations are made:

1. There should be establishment of Research and management unit Open and distance Education in university where students can learn computer and software development.

2. The university should provide relevant and current online education facilities available to the students, especially in their subject combination. Also information on online education in their respective discipline should be gradually incorporated by the department of which they belong to.

\section{REFERENCES}

Adedoja, G.O. and Abimbade, O.A. (2010). University of Ibadan Lecturers' Level of Readiness and Perceived Role toward Mobile Instruction. Nigeria Journal for Computer Literacy. 11(1). 29-44

Adedoja, G. \& Abimbade, O. (2013). Social studies teachers' intention to use mobile phones as a support and tutorial tool for teaching,2013 IST-Africa Conference \& Exhibition, Nairobi, Kenya, 1-8.

AbdulHameed, K.A. (2004). Assessing the Awareness and perceptions of Academic staff in using E-learning tools for Instructional Delivery in a post-secondary institution: A case study of universities Putra Malaysia. The Public Sector Innovation Journal, 1(3), 2-11p.

Annemieke, C., Annegret, G., \& Jamie, M. (2008). Perceptions of Roles and Responsibilities in Online Learning. Interdisciplinary Journal of E-learning and Learning Objects, 4, 205$222 p$.

Atienza-Venal, M.C. (2009). Readiness of Computer Engineering Students of TIPQC to Online Learning. Journal of Computer and Electrical Engineering 2, 231-235p.

Aytekin, I and Zehra, A. (2006). Self-perceptions and Roles: How East Mediterranean University Students and Teachers view online programmes and courses. Turkish online Journal of Distance Education, 7(1), 75-90. Retrieved from www.todje.eau.edu.tr.

Ben, E. (2007). Facilitating student readiness for online education.

Bernard, A. (2004). Students' Readiness for Online Learning: A case study from the Faculty of Education, University of Malta. Journal of Maltese Education Research 2(2), 46-59p. 
Carla, T. (2007). Evaluating E-learning Readiness in a health sciences Higher Education Institution. Paper presented at IADIS International Conference on E-learning, Porto, Portugal. Retrieved from www.learningcircuit.org.

Carol, K. (2000). The impact of technology on learning. Retrieved from www.mcrel.org.

Chan, Y.F. and Norassah, A. (2011). Pre-service Teachers' Training in Information Communication and Technology for Esl Classrooms in Malaysia. Turkish Online Journal of Distance Education, 11(3), 1-11. Retrieved from www.todje.tr.

Chiang, Y.C., Ahmed, F.M. and Wong, S.L. (2010). Students' Readiness in using Mathematics Online Portal: A preliminary study among undergraduates in Malaysia. Retrieved from WwW.sciencedirect.org.

Chen.chang, P., Stephen, S. Glenda, G. \& Richard, C. (2005). Students' perceived ease of use of an E-learning Management System: An Exogenous or Endogenous variable? Journal of Educational Computing Research, 33(3), 285-307p. Retrieved from www.jecr.org.

Christie, M. and Garrote, R.J. (2008). Barriers to Innovation in Online Pedagogy. Retrieved on from www.ituniv.se.

Danielle Herro, Cassie Quigley, Holly Plank \& Oluwadara Abimbade (2021): Understanding students' social interactions during making activities designed to promote computational thinking, The Journal of Educational Research, DOI:10.1080/00220671.2021.1884824

Esobi, I. C., Lasode, M. K., Anyanwu, C. I., Degbe, E., Barriguete, M. F., Okorie, M. A., ... \& Okegbe, S. (2020). Nutritional Impact of COVID-19 and Its Implications on Atherosclerosis. World, 8(1), 16-21.

Esobi, I. C., Lasode, M. K., Anyanwu, C. I., Barriguete, M. F., Okorie, M. A., \& Lasode, D. O. (2021). Food Insecurity, Social Vulnerability, and the Impact of COVID-19 on Population Dependent on Public Assistance/SNAP: A Case Study of South Carolina, USA. Journal of Food Security, 9(1), 8-18.

Fakayode, B., \& Okegbe, S. (2021). Using a Mobile-Based Online Platform to Mentor Girls: Challenges and Benefits.

Fred, A.G. (2003). Teacher and student perceptions of Online Instructional Methodology in Higher Education: An Explanatory Mixed. Method study. An unpublished Ph.D Dissertation, Louisianan State University, U.S.

George, S. (2004). A learning theory for the Digital Age. Retrieved from www.ymlp.com 
George, S. (2006). A Review of Learning Management System Reviews. Retrieved on December, 30, 2010 from www.ymlp.com

Hasnah, T.K. Wong, S.L., Ahmad, F. and Rosnain, M. (2009). A review of the Literature: Determinants of Online Learning among students. European Journal of Social Sciences, 8(2), 246-252p. Retrieved from www.ejss.org

Ibrahim, A.A. Noraidah, S. and Mustasem, A. (2011). Acceptance of Learning Management System: A Comparison between Distance learners and instructor. Journal of Advanced Information Sciences and service sciences, 3, 5, Retrieved from www.iupui.edu.

Karen, K., Jamie, S. and Gene, C. (2009). Workforce Readiness: A study of University students' fluency with Information Technology. Journal of Computers and Education, 53, 228-233p. Retrieved from www.elsevier.com/locate/compedu.

Katarzyna, M. and Jerzy, R. (2010). Barriers to Introduction of E-learning: A case study paper presented at IEEE Global Engineering Education Conference, Amman, Jordan. Retrieved from www.educon.com

Kuldip, K. and Zorain, W.A. (2004). An Assessment of E-learning Readiness at the Open University Malaysia. Paper presented at the International Conference on Computer in Education, Melbourne, Australia. Retrieved from www.infodev.org/library/ICCE

Lim, B., Hong, K.S; and Tan, K.W. (2008). Acceptance of E-learning among Distance Learners: A Malaysian Perspective. Retrieved from www.ascillite.org.au/conferences/melbourne08/procs/lim.pdf

Lou. S and Kathryn, C.D. (2008). Planned Behaviour: Student Attitudes Towards the use of ICT Interaction in Higher Education. Retrieved from Www.ascillite.org.aulconferences/melbourne08/process/siragusa.pdf

Mac Adkins (2010). The 2010 Student Readiness Report Identifies Trends Among Online Learners Retrieved from www.smarteservices.com

Malaya, K.N. and Poonphon, S. (2007). Advantages and Disadvantages of E-learning Management System Retrieved from www.cide.au.

Matjaz, D. and Juliza, L.B. (2006). Usability testing of E-learning content as used in two learning management systems. Retrieved from www.uni-mb.si

Margret, H. and Katherin, M.C. (2005). Critical Issue: Using Technology to Improve Student Achievement. Retrieved from www.ncrel.org 
Milan, K. and Zuzana, H. (2009). Computers in Human Behaviour: Slovak High School Students' Attitudes to ICT using in Biology lesson. Retrieved from www.elsever.com

Okegbe, S. (2021). Understanding the Role of Tacit Knowledge in Call-Center Organizations.

Sanmi, M., Awoleye, O; and Egbetokun, A.A. (2009). Harnessing the potentials of Internet Technology for Research and Development among undergraduates in Nigeria: A case study of OAU. International Journal of Computing and ICT Research, 3, 1, Retrieved from www.ijci.org.

Stephen, A.S. and cheu-chang, P. (2010). Undergraduate Engineering and Psychology Students' use of a course management system: A factorial invariance study of user characteristics and attitudes. The Journal of Technology studies, 31, Retrieved fromwww.jts.org

Suzzane, D. (2009). Connectivism Learning Theory: Instructional Tools for college Courses Retrieved from www.connectism.ca

Timothy, O.A.; Ibrahim, O.A. and Femi, A.A. (2008). E-learning and Distance Education in Nigeria. The Turkish Online Journal of Educational Technology, 7, 4, Retrieved from www.tojet.tr

Wade, W.F. and Peggy, B.G. (2009). Perceptions of Online Instruction. Turkish Online Journal of Educational Technology, 8, 53-64. Retrieved from www.toget.tr

World Bank, (2007). Nigeria country Brief. Retrieved from www.worldbank.og/WBSITE/EXTERNAL/COUNTRIES/AFRICAE)NIGERIAETN 